\title{
TRENDS AND FEATURES OF EU COHESION POLICY IMPLEMENTATION FOR OLD AND NEW MEMBER STATES
}

\author{
Ona Gražina RAKAUSKIENĖ \\ Mykolas Romeris University, Institute of Economics and Business \\ Ateities st. 20, LT-08303 Vilnius, Lithuania \\ E-mail: ona.rakaus@mruni.eu \\ Viktor KOZLOVSKIJ \\ Mykolas Romeris University, Institute of Economics and Business \\ Ateities st. 20, LT-08303 Vilnius, Lithuania \\ Vilniaus kolegija/University of Applied Sciences, Business Management Faculty \\ Didlaukio st. 49, LT-08303 Vilnius, Lithuania \\ E-mail: v.kozlovskij@vvf.viko.lt
}

doi:10.13165/IE-13-7-2-01

\begin{abstract}
The European Union's increasing international activity and significant role in the world economy attaches the growing importance to the processes taking place in the economic life of the new Europe in the context overcoming the consequences of economic crisis. A variety of questions arise in the process, such as why is it that some EU economies overcome the crisis more successful on their development, whereas other economies are in stagnation, with a near zero or negative growth rates? What changes, both positive and negative, have taken place in the economies of old and new EU Member States? Is the enlargement of the EU economically justified? Is the development of the EU heading in the right direction? Were mistakes made in adopting the decision for the EU enlargement?

This process carries both new threats and opportunities for development. Whether the situation will be favourable for the sustainable and effective development of the EU economy depends on the implementation of the EU's cohesion policy and the response to the new challenges of the pursued cohesion policy in the future.

Social and economic cohesion is an expression of solidarity among the Member States and regions of the EU territorial level. The aim is to achieve balanced development throughout the EU by reducing structural disparities among countries and regions and promoting equal opportunities for all. Cohesion policy has a major impact on the economies of the Member States, reducing economical differences and promoting environmental and social development. It has also played a crucial role with European Structural funds helping to cushion the impact of the crisis on the economies of the EU Member States, their citizens and businesses.

The EU Member States are characterized by the large disparity in the development level - it can be said that the EU is a multi-speed Europe: the EU old members' and the EU new members' social and economic development varies significantly. Moreover, EU countries
\end{abstract}


(including the two groups inside) show convergence and divergence processes of economic and social cohesion at the same time.

The purpose of this article is to raise the role of the economic and social cohesion to the EU Member States economies, highlighting the EU's cohesion policy trends and characteristics.

JEL classification: J64, O11.

Keywords: regional territorial, economic and social cohesion, relative GDP, GDP growth, social economic inequality, inflation, government budget, government debt, convergence, divergence.

Reikšminiai žodžiai: regioninė teritorinè, ekonominė ir socialinė sanglauda, santykinis BVP, BVP augimas, socialinè ekonominè nelygybè, infliacija, valstybės biudžetas, valstybès skola, konvergencija, divergencija.

\section{Introduction}

Sustainable regional development and cohesion problems renew after the EU expansion, foremost due to the increasing inter-regional socio-economic differences in appreciation of both national and international levels. The researchers' studies were used to show the widening gap between Eastern and Western European countries and regions, between the central and peripheral regions and that metropolitan areas' (often capitals') polarization takes place. Empirical studies have shown that within the EU there are significant social and economic disparities that are clearly reflected in the most recent reports on the EU's economic and social cohesion, which emphasizes that the internal differences increased primarily due to the joining of Central and Eastern European countries.

In fact, Europe is divided into two parts - Western Europe and Eastern Europe. One group of politicians having no doubts about the development of the EU supports the concept of the development of a 'two-speed' Europe - let the new EU Member States continue integrating and attain the current level of integration, while the 'hardcore', or the most advanced Member States, must take the road of a deeper integration, i.e., a certain vanguard group will function within the EU confederation and will also have to assume, in proportion to its economic weight, an appropriate political responsibility for the development of the entire EU. According to this view, the enlarged EU must be left as it is today, but the so-called euro-area Member States will move forward, i.e., will integrate in a comprehensive manner.

Another group of politicians has a different vision of the EU's future and claims that the division of the EU into two unequal parts is impermissible. For all the countries to accept and develop trust in the project of a unified European Union, the economy of the entire EU must be oriented towards enhancement of competitiveness and aim at achieving a true equality between the states. In order to achieve a breakthrough in this field, a much deeper mutual understanding and co-operation between the new and old EU Member States is needed.

A particular problem is compliance with provisions of the EU Stability and Growth Pact and the Maastricht criteria with a view to entering the EMU. A debate about im- 
plementation of the Stability Pact under the conditions of the crisis became especially heated in 2008-2010. Presently, two directions are clearly visible and constitute double standards policy. In the old Member States of the EU (Germany, France, Great Britain), the overcoming of the crisis is linked with loosening of the fiscal policy, i.e., in aiming to promote economic growth and reduce unemployment, increase state expenditure and reduce taxes. In a number of weaker (Greece, Spain, Portugal, Italy) and the new EU Member States (Lithuania, Latvia, Estonia), the EU fiscal policy reforms are being implemented during the crisis in an opposite manner - by increasing taxes and reducing the expenditure of the state budget. So far, it is not possible to claim that these countries are successful in combating the crisis and the economic decline.

The current economic problems in the world and Europe are forcing to pay more and more attention to the EU Member States and regional disparities. The EU 2020 Strategy underlines the role of structural economic policy and states that the crisis has wiped out over the years, sought economic and social progress and exposed structural weaknesses in the European economy. Drastic changes in the world economy are taking place and long-term problems are appearing, such as globalization, exhaustion of resources, aging, social and economic inequalities.

\section{EU cohesion policy concept and research methodology}

In the economics literature, the definition of cohesion is not a simple concept and can be interpreted in different ways (Calvo et al., 2004). For some, it means the territorial and social relations stability; for others, the process of convergence between regions and social groups. Moreover, some scientists even narrow the concept till employment opportunities and preferred living standards. Cohesion policy's aim can be to equilibrate regional and social disparities within the transparent redistribution of GDP, employment, etc., or cohesion policy can be directed to the maximal contribute from regions and social groups to the country's economic performance, etc. (Chan, 2006; Hulse and Stone, 2007).

The term "cohesion" in the context of the EU started being used relatively recently: just in the beginning of this century. Until then, the concept of "convergence" (as well as its antonym "divergence") or "integration" was used widespread.

No less important is to accurately grasp the cohesion policy definition. As it can be seen from the above mentioned facts, the concept of cohesion policy in the EU context also appeared at the time. Although the part of the Treaty of Rome for social and economic cohesion occurred in 1986 (when the Single European Act was signed), the term "cohesion policy" appeared just during the programming period of 2000-2006. Until then, the concept of structural policy was usually used in the EU official documents. Of course, the structural and cohesion policies are not identical. The cohesion policy supports territorial, economic and social cohesion in the whole $\mathrm{EU}$ and its individual regions and in the countries' in macro-economic and micro-economic levels. The structural policy covers all EU countries and regions and all areas and sectors related to microeconomics. In the authors' opinion, the cohesion policy is in a sense a broader concept for the structural policy.

The relationship between economic, social and territorial (regional) cohesion policies is not unambiguous and simple. Cohesion policy elements should be more or less equivalent (Fig. 1). 
Figure 1. Structure of cohesion policy (equal parts)

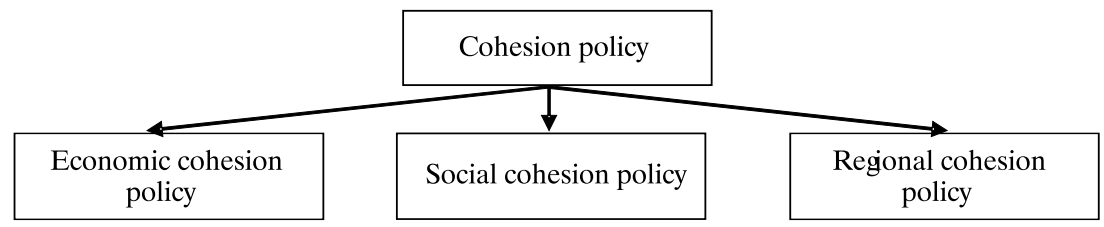

Analysis of EU documents (The EU 2020 Strategy, Reports on Economic, Social and Territorial Cohesion, etc.) gives the impression that the cohesion policy is equated with the territorial (regional) policy, which constituent component are economic and social cohesions. However, in the authors' view, the cohesion should be seen as a three or four (following the tradition of the sustainable development concept, the ecological development component should be kept in mind) equal parts integration (Fig. 2).

Figure 2. Structure of cohesion policies (on the basis of definition analysis)

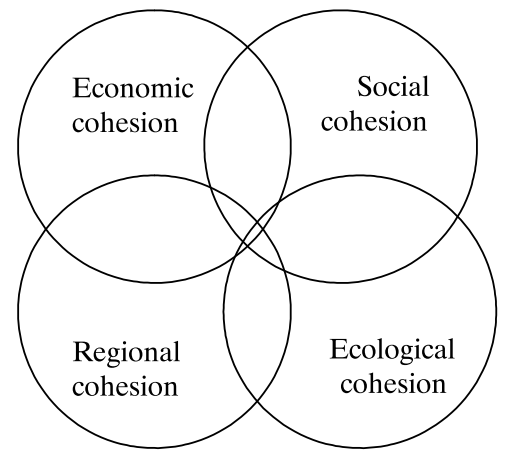

Territorial cohesion is major for the EU, and, of course, combines the strong integration of the economic and social components (e.g., the problem of unemployment has economic, social and territorial sides). However, there are other aspects of the territorial cohesion, which may be none the less significant, e.g., geography, climate change. Also, the EU social cohesion is not necessarily linked to the territorial aspect, e.g., political structures, EU military security assurance, etc. Finally, the economic cohesion has, for example, economic cycles' unification aspect, which with time depends less on regional distribution.

Economic aspect of EU cohesion policy. EU cohesion policy and its understanding of the economic aspect can be divided into three parts: economic, financial and technology/innovative cohesion. Almost all the reports (e.g., The EU 2020 Strategy; Economic, Social and Territorial Cohesion, etc.) and studies (Barry, 2003; Garcia, 2003; Begg, 2003; etc.) reflect the same basic economic indicators of cohesion analysis (Fig. 3). 
Figure 3. Economic aspect of cohesion and main indicators

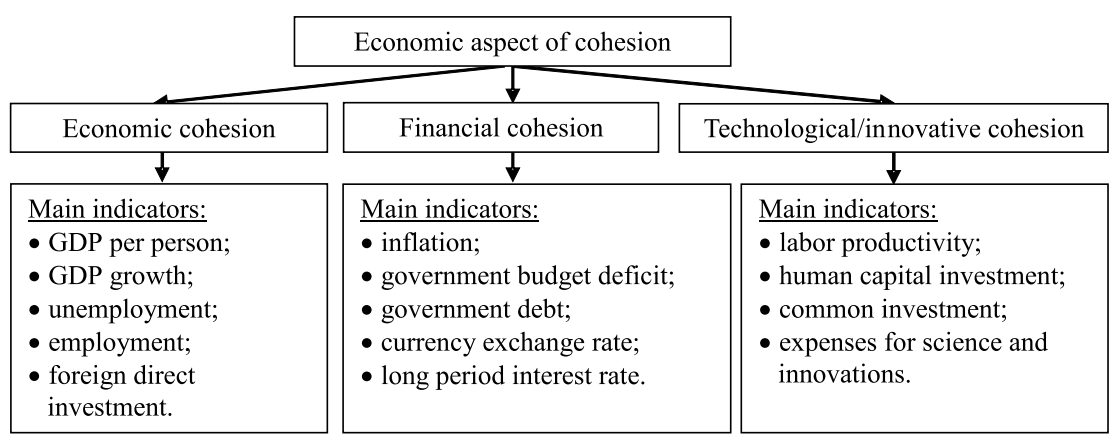

Usually, the economic cohesion in the EU is being measured just by the key macroeconomic indicators such as GDP, inflation, budget deficit, national debt, the interest rate, etc. Moreover, the spectre of the indicators rapidly narrows, when EU cohesion policy instruments are going to be used - the main and practically the only economic indicator of regions' inequality is GDP per capita. This can be seen as a major weakness of the EU's cohesion policy, which is often criticized (Calvo et al., 2004).

Another very important component of the economic cohesion is the financial cohesion. The EU created the EMU, which should facilitate the EU Member States and the economic cohesion. The official EU (the EU Parliament, the European Commission, the European Central Bank, etc.) recognizes the importance of the so-called Maastricht criteria, as well as some scholars (e.g., Barry, 2003; Begg, 2003). Other researchers (e.g., Buiter, Corsetti, Roubini, 1993; Fitoussi, Sen, Stiglitz, 2009) consider the above mentioned criteria as "economic nonsense" that is not based on economic theory and practical tests.

The authors distinguish the technological/innovative cohesion as the third part of the economic cohesion. Technology and innovation development is one of the key objectives of the EU policy and - it should be stressed - is one of the major growth and competitiveness drivers, which are appointed by the respective structural funds.

Social aspect of the EU cohesion policy. The Council of Europe's Strategy for Social Cohesion in its document (Battaini-Dragoni, Dominioni, 2003) gives three aspects of the perception of the social cohesion.

First, the social cohesion is perceived as a dependency of shared values, a feeling of solidarity (Hulse, Stone, 2007; Stanley, 2001). Thus, the social cohesion refers to all social processes that help people feel that they belong to the same community and identify themselves as belonging to the community.

Secondly, the social cohesion is the commitment and the ability to work together: the social cohesion is a situation, in which a group of people (defined geographical region, country, etc.) demonstrates the ability to collaborate and communicate, creating changes in the atmosphere (Dragojevic, 2001).

Third, the social cohesion emphasizes social connections and relationships, revealing the etymological sense of the term. The social cohesion is a promotion program for stable, solidary and sustainable communities. 
Social cohesion key trends are:

employment and income distribution (the problem of unemployment, especially among young people, long-term unemployment, job creation, income distribution inequality, etc.);

- $\quad$ social protection (social security, poverty reduction, social inclusion, etc.);

- $\quad$ living conditions (housing, access to services, etc.);

- $\quad$ educational services (services of education and literacy levels, etc.);

- social services.

EU regional territorial cohesion. The notion of region is very popular in scientific studies. However, the concept is not unambiguous and indisputable. In the discourse, the question whether the region is an objective or subjective category has been developed for a long time in the scientific literature on the subject (Kosiedowski, 2001). In various studies, which includes regions, they are perceived relatively abstract, suggesting that the region is (Burbulyte, 2005):

- the country or area of the world with definable characteristics but not always fixed boundaries;

- each of the Earth's surface area with natural or artificial features distinctive from other areas;

- more or less defined territory, characterized by a certain integrity and management principles that distinguish it from other regions;

- generally a single area that according to the selected criteria is different from other neighbouring areas.

The EU territorial cohesion objective is to reduce inequalities of the EU Member States and regions and to ensure sustainable development of geographical areas (also with specific features and specifications), estimating how the cohesion policy and other EU sectoral policies can be best adapted to the situations in these areas.

Territorial agenda sets three cohesion priorities:

- through the national and regional territorial development policy focus on better employment of territorial advantages;

- to enhance spatial connections and integrate the territories to promote cooperation and exchanges;

- to improve EU policies that give spatial effects, compatibility.

As it was mentioned earlier, the regional cohesion policy is the basis of the EU cohesion policy. Its aim is to work out regional problems of uneven economic development (particularly, economic growth and income). While State experiences economic stagnation or downturn, the priority is given to the economic growth, but when a certain level is reached, there is a growing emphasis on the social component of the regional policy (e.g., convergence of the quality of life among regions).

\section{Inequality features of the economic and social cohesions of the EU Member States}

The analysis shows that the EU Member States are characterized by a large disparity in the development during 2000-2011 periods - it can be said that there is a two-speed 
Europe: social and economic development of the EU old Member States and the EU newcomers varies significantly. Moreover, EU countries (including the inside of the mentioned two groups) face the convergence and divergence processes in the economic and social cohesion at the same time. For further analysis, three main EU indicators were selected: GDP per capita (at purchasing power parity) and GDP growth rates, which are used in the analysis of macro-economic convergence level, and income inequality indicators of countries, reflecting the social cohesion of the Maastricht criteria (inflation, budget deficit and public sector debt) context. The development of the $\mathrm{EU}$ can be divided into three phases: before the EU's biggest enlargement of 2000-2004, following this enlargement the period of 2005-2008 and decline after the global crisis and recovery period of 2009-2011.

\subsection{EU Member States disparity in GDP level}

The analysis of the relative GDP changes leads to the conclusion that the EU's economic cohesion policy was relatively effective during the period of economic prosperity, but encountered difficulties during the economic downturn.

Even before the EU enlargement in 2004, the more developed countries (EU-15) had different relative level of GDP (Table 1).

Table 1. Old EU Member States GDP per capita in 2000-2011, \% EU-27 average

\begin{tabular}{|l|c|c|c|c|}
\hline & $\mathbf{2 0 0 0}$ & $\mathbf{2 0 0 4}$ & $\mathbf{2 0 0 8}$ & $\mathbf{2 0 1 1}$ \\
\hline EU-27 & 100 & 100 & 100 & 100 \\
\hline The Netherlands & 134 & 129 & 134 & 131 \\
\hline Austria & 132 & 128 & 124 & 129 \\
\hline Ireland & 132 & 143 & 133 & 127 \\
\hline Sweden & 128 & 126 & 124 & 126 \\
\hline Denmark & 132 & 126 & 125 & 125 \\
\hline Germany & 118 & 115 & 116 & 120 \\
\hline Belgium & 126 & 121 & 116 & 118 \\
\hline Finland & 117 & 116 & 119 & 116 \\
\hline The United Kingdom & 119 & 124 & 112 & 108 \\
\hline France & 115 & 110 & 107 & 107 \\
\hline Italy & 119 & 107 & 104 & 101 \\
\hline Spain & 97 & 101 & 104 & 99 \\
\hline Greece & 84 & 94 & 92 & 82 \\
\hline Portugal & 81 & 77 & 78 & 77 \\
\hline
\end{tabular}

Source: Eurostat data.

By the change in GDP per capita all old members of the EU can be divided into three groups. The first group is characterized by a decline in a relative GDP (the Netherlands, Denmark, Belgium, Italy and Portugal). However, there can be seen two subgroups in this group of countries. If the decline in the relative GDP in the first three of these countries can be explained by convergence (the relative GDP becomes closer to the EU average), divergence trend can be revealed in Italy and Portugal cases. The second group of 
countries is where the relative GDP grew during the period: Austria, Ireland, the United Kingdom, Spain and Greece. Also, two subgroups can be distinguished: the first, when the rate change can be explained by the economic cohesion process (Spain and Greece) and the second, when the relative GDP growth reflects the growing gap with the EU (Austria, Ireland and the United Kingdom). The third group maintained relatively equal positions (Sweden, Germany, Finland and France).

After the EU enlargement in 2004, the situation changed - the economic convergence trends of the old EU Member States intensified when analyzed in the macroeconomic level. During this period, only three of the more developed EU countries showed a relative growth of GDP while being far from the EU average. These countries include the Netherlands, Ireland and Spain. A much greater number of countries showed a relative decline in GDP and drawing near the EU average: Denmark, Belgium, the United Kingdom, France, Italy and Portugal. Five countries (Austria, Sweden, Germany, Finland and Greece) ratio remained at the same level.

The 2009-2011 period led to a major challenge for the EU and its members. The global crisis, followed by recession and difficult recovery, weakened economic positions of almost all EU member states. On the other hand, a disturbing trend can be noted that the more developed member countries outlived this period relatively easier than most of the economically weaker countries. First, Austria's, Sweden's, Germany's and Belgium's relative GDP during this period increased from 118-125 percent up to 119-129 percent. Another five countries (the Netherlands, Denmark, Finland, the United Kingdom and France) remained stable, while the four least developed countries (Italy, Spain, Greece and Portugal) ratio decreased from 78-104 percent even to 77-101 percent.

Table 2. New EU Member States GDP per capita in 2000-2011, \% EU-27 average

\begin{tabular}{|l|c|c|c|c|}
\hline & $\mathbf{2 0 0 0}$ & $\mathbf{2 0 0 4}$ & $\mathbf{2 0 0 8}$ & $\mathbf{2 0 1 1}$ \\
\hline EU-27 & 100 & 100 & 100 & 100 \\
\hline Cyprus & 88 & 90 & 98 & 92 \\
\hline Slovenia & 80 & 87 & 91 & 84 \\
\hline Malta & 85 & 78 & 79 & 83 \\
\hline The Czech Republic & 71 & 78 & 81 & 80 \\
\hline Slovakia & 50 & 57 & 73 & 73 \\
\hline Estonia & 45 & 57 & 69 & 67 \\
\hline Hungary & 54 & 63 & 64 & 66 \\
\hline Poland & 48 & 51 & 56 & 65 \\
\hline Lithuania & 40 & 51 & 61 & 62 \\
\hline Latvia & 36 & 46 & 56 & 58 \\
\hline Romania & 26 & 34 & 47 & 49 \\
\hline Bulgaria & 28 & 35 & 44 & 45 \\
\hline
\end{tabular}

Source: Eurostat data.

The relative GDP in the 2000-2011 analysis of the EU newcomers shows that the economic cohesion of these countries was very strong before accession and the first five years after it: their GDPs were approaching the EU average (Table 2).

Almost all EU newcomers (except more prosperous Cyprus and Malta, which relative GDPs remained relatively constant) prior to the accession to the EU showed a stable 
approximation to the EU average. A similar situation was during the economic growth period of 2005-2008, when the relative GDPs of almost all countries (with the exception of Hungary, where the indicator declined) were rapidly approaching to the EU average.

The opposite view can be noticed in 2009-2011. The recession and the difficult period after it are marked by stagnation (Malta's, Slovakia's, Estonia's, Hungary's, Romania's and Bulgaria's relative GDPs remained stable) or the relative deterioration of the situation (Cyprus', Slovenia's and the Czech Republic's relative GDPs declined). Only Poland, where there was no decline at all, continued to move towards the EU average.

\subsection{EU Member States economic growth - convergence and divergence}

A stronger economic cohesion can be spotted between the EU Member States during the period of 2000-2008. Meanwhile, during the global crisis, the recession and the recovery period (2009-2011), a strong divergence trend is needed to be noted.

Table 3. Old EU Member States real GDP growth in 2000-2011, \%

\begin{tabular}{|l|c|c|c|c|c|c|c|c|c|c|c|c|}
\hline & $\mathbf{2 0 0 0}$ & $\mathbf{2 0 0 1}$ & $\mathbf{2 0 0 2}$ & $\mathbf{2 0 0 3}$ & $\mathbf{2 0 0 4}$ & $\mathbf{2 0 0 5}$ & $\mathbf{2 0 0 6}$ & $\mathbf{2 0 0 7}$ & $\mathbf{2 0 0 8}$ & $\mathbf{2 0 0 9}$ & $\mathbf{2 0 1 0}$ & $\mathbf{2 0 1 1}$ \\
\hline EU-27 & 3.9 & 2.1 & 1.3 & 1.5 & 2.5 & 2.1 & 3.3 & 3.2 & 0.3 & -4.3 & 2.1 & 1.5 \\
\hline Luxembourg & 8.4 & 2.5 & 4.1 & 1.7 & 4.4 & 5.3 & 4.9 & 6.6 & -0.7 & -4.1 & 2.9 & 1.7 \\
\hline The Netherlands & 3.9 & 1.9 & 0.1 & 0.3 & 2.2 & 2.0 & 3.4 & 3.9 & 1.8 & -3.7 & 1.6 & 1.0 \\
\hline Austria & 3.7 & 0.9 & 1.7 & 0.9 & 2.6 & 2.4 & 3.7 & 3.7 & 1.4 & -3.8 & 2.1 & 2.7 \\
\hline Ireland & 10.7 & 5.3 & 5.6 & 3.9 & 4.4 & 5.9 & 5.4 & 5.4 & -2.1 & -5.5 & -0.8 & 1.4 \\
\hline Sweden & 4.5 & 1.3 & 2.5 & 2.3 & 4.2 & 3.2 & 4.3 & 3.3 & -0.6 & -5.0 & 6.6 & 3.9 \\
\hline Denmark & 3.5 & 0.7 & 0.5 & 0.4 & 2.3 & 2.4 & 3.4 & 1.6 & -0.8 & -5.7 & 1.6 & 1.1 \\
\hline Germany & 3.1 & 1.5 & 0.0 & -0.4 & 1.2 & 0.7 & 3.7 & 3.3 & 1.1 & -5.1 & 4.2 & 3.0 \\
\hline Belgium & 3.7 & 0.8 & 1.4 & 0.8 & 3.3 & 1.8 & 2.7 & 2.9 & 1.0 & -2.8 & 2.4 & 1.8 \\
\hline Finland & 5.3 & 2.3 & 1.8 & 2.0 & 4.1 & 2.9 & 4.4 & 5.3 & 0.3 & -8.5 & 3.3 & 2.7 \\
\hline $\begin{array}{l}\text { The United } \\
\text { Kingdom }\end{array}$ & 4.2 & 2.9 & 2.4 & 3.8 & 2.9 & 2.8 & 2.6 & 3.6 & -1.0 & -4.0 & 1.8 & 0.9 \\
\hline France & 3.7 & 1.8 & 0.9 & 0.9 & 2.5 & 1.8 & 2.5 & 2.3 & -0.1 & -3.1 & 1.7 & 1.7 \\
\hline Italy & 3.7 & 1.9 & 0.5 & 0.0 & 1.7 & 0.9 & 2.2 & 1.7 & -1.2 & -5.5 & 1.8 & 0.4 \\
\hline Spain & 5.0 & 3.7 & 2.7 & 3.1 & 3.3 & 3.6 & 4.1 & 3.5 & 0.9 & -3.7 & -0.3 & 0.4 \\
\hline Greece & 3.5 & 4.2 & 3.4 & 5.9 & 4.4 & 2.3 & 5.5 & 3.5 & -0.2 & -3.1 & -4.9 & -7.1 \\
\hline Portugal & 3.9 & 2.0 & 0.8 & -0.9 & 1.6 & 0.8 & 1.4 & 2.4 & 0.0 & -2.9 & 1.4 & -1.7 \\
\hline
\end{tabular}

Source: Eurostat data. ${ }^{1}$

It clearly demonstrates the trend that major EU members' real GDP growth rates are slower than the growth rate of the whole EU in almost all the analyzed period of ten years. These are countries, such as Germany, France, Italy and the United Kingdom, unlike the situation in Spain and Greece, which real GDPs grew faster than the EU as a whole almost all the time. Only in recent years, situations in Greece and Spain have changed dramatically. These two countries, along with Portugal, have shown the worst GDP growth performance across the EU for the last 2-3 years. The reasons of it are totally ambiguous and require scientific research.

1 Coloured indicator's values, which are lower than the EU average. 
Another important trend showed that the most developed countries maintained higher growth rates in the long term. These countries included Luxembourg, Austria, Ireland, Sweden and Finland. So, they became even more alienated from the other EU member states.

Table 4. New EU Member States real GDP growth in 2000-2011, \%

\begin{tabular}{|l|c|c|c|c|c|c|c|c|c|c|c|c|}
\hline & $\mathbf{2 0 0 0}$ & $\mathbf{2 0 0 1}$ & $\mathbf{2 0 0 2}$ & $\mathbf{2 0 0 3}$ & $\mathbf{2 0 0 4}$ & $\mathbf{2 0 0 5}$ & $\mathbf{2 0 0 6}$ & $\mathbf{2 0 0 7}$ & $\mathbf{2 0 0 8}$ & $\mathbf{2 0 0 9}$ & $\mathbf{2 0 1 0}$ & $\mathbf{2 0 1 1}$ \\
\hline EU-27 & 3.9 & 2.1 & 1.3 & 1.5 & 2.5 & 2.1 & 3.3 & 3.2 & 0.3 & -4.3 & 2.1 & 1.5 \\
\hline Cyprus & 5.0 & 4.0 & 2.1 & 1.9 & 4.2 & 3.9 & 4.1 & 5.1 & 3.6 & -1.9 & 1.3 & 0.5 \\
\hline Slovenia & 4.3 & 2.9 & 3.8 & 2.9 & 4.4 & 4.0 & 5.8 & 7.0 & 3.4 & -7.8 & 1.2 & 0.6 \\
\hline Malta & $:$ & -1.5 & 2.8 & 0.1 & -0.5 & 3.7 & 3.2 & 4.6 & 4.0 & -2.4 & 3.4 & 1.9 \\
\hline $\begin{array}{l}\text { The Czech } \\
\text { Republic }\end{array}$ & 4.2 & 3.1 & 2.1 & 3.8 & 4.7 & 6.8 & 7.0 & 5.7 & 3.1 & -4.5 & 2.5 & 1.9 \\
\hline Slovakia & 1.4 & 3.5 & 4.6 & 4.8 & 5.1 & 6.7 & 8.3 & 10.5 & 5.8 & -4.9 & 4.4 & 3.2 \\
\hline Estonia & 9.7 & 6.3 & 6.6 & 7.8 & 6.3 & 8.9 & 10.1 & 7.5 & -4.2 & -14.1 & 3.3 & 8.3 \\
\hline Hungary & 4.2 & 3.7 & 4.5 & 3.9 & 4.8 & 4.0 & 3.9 & 0.1 & 0.9 & -6.8 & 1.3 & 1.6 \\
\hline Poland & 4.3 & 1.2 & 1.4 & 3.9 & 5.3 & 3.6 & 6.2 & 6.8 & 5.1 & 1.6 & 3.9 & 4.3 \\
\hline Lithuania & 3.6 & 6.7 & 6.8 & 10.3 & 7.4 & 7.8 & 7.8 & 9.8 & 2.9 & -14.8 & 1.5 & 5.9 \\
\hline Latvia & 5.7 & 7.3 & 7.2 & 7.6 & 8.9 & 10.1 & 11.2 & 9.6 & -3.3 & -17.7 & -0.9 & 5.5 \\
\hline Romania & 2.4 & 5.7 & 5.1 & 5.2 & 8.5 & 4.2 & 7.9 & 6.3 & 7.3 & -6.6 & -1.6 & 2.5 \\
\hline Bulgaria & 5.7 & 4.2 & 4.7 & 5.5 & 6.7 & 6.4 & 6.5 & 6.4 & 6.2 & -5.5 & 0.4 & 1.7 \\
\hline
\end{tabular}

Source: Eurostat data. ${ }^{2}$

EU divergence processes intensified during the downturn. This has been one of the most important challenges in the last years for the EU cohesion policy.

Looking at the new members' results, a logical trend can be seen that almost all countries showed a higher rate of economic growth than the rest of the EU throughout the period from 2000 to 2008. If countries-newcomers want to reach the EU average, they need to grow much faster than the old ones. On the other hand, the biggest threat to the country's economic growth has emerged during the recession. Exactly these countries (except for Poland, Malta and Cyprus) had the highest rate of GDP decline, and some countries (Estonia, Latvia and Romania) extended the period of the decline.

\subsection{Socio-economic inequalities in the EU Member States}

Analysis of income inequality in the EU Member States shows that there is a correlation between the achieved economic development level and socio-economic inequality.

2 Coloured indicator's values, which are higher than the EU average. 
Table 5. Distribution of income inequality in the EU Member States by the quintile differentiation coefficient $\mathrm{K}_{\mathrm{kv}}{ }^{3}$

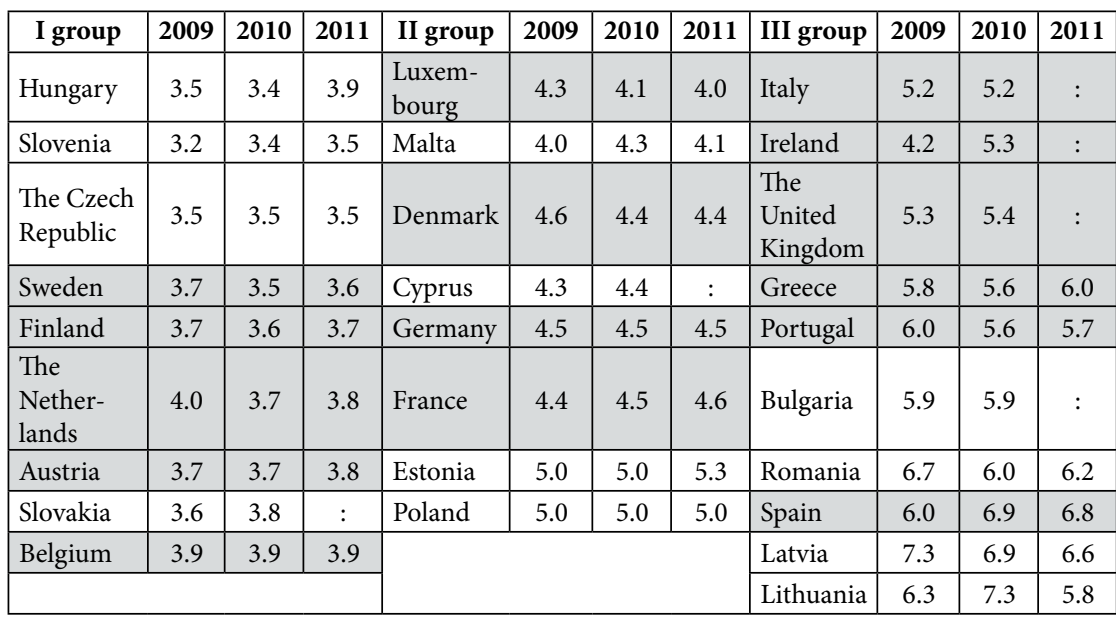

Source: Eurostat data.

According to $\mathrm{K}_{\mathrm{kv},}$ all EU member states can be divided into three groups (Table 5): the first group includes the countries with the smallest income differences $\left(\mathrm{K}_{\mathrm{kv}}\right.$ from 3.4 to 4.0): Hungary, Slovenia, the Czech Republic, Sweden, Finland, the Netherlands, Austria, Slovakia and Belgium; the countries with average income inequality belong to the second group ( $\mathrm{K}_{\mathrm{kv}}$ from 4.0 to 5.0): Luxembourg, Malta, Denmark, Cyprus, Germany, France, Estonia and Poland; the third group is characterized by extremely high income inequality ( $\mathrm{K}_{\mathrm{kv}}$ from 5.0 to 7.3): Italy, Ireland, the United Kingdom, Greece, Portugal, Bulgaria, Romania, Spain, Latvia and Lithuania. It should be noted that Lithuania has one of the highest income inequalities in the European Union.

New and old EU Members States were evenly distributed across all three groups. Thus, income inequality does not depend on the country's EU accession period.

There is a tendency that to the first group of countries belong states, which were showing better results during the economic growth and suffered the recession more easily. These countries are Sweden, Finland, the Netherlands, Austria, Belgium, Slovenia, the Czech Republic and Slovakia. The third group of countries faced supreme difficulties in the EU during the economic downturn. These countries include Italy, Ireland, Greece, Portugal and Spain.

It should be noted that the third group unites the most lagging EU countries: Lithuania, Latvia, Romania and Bulgaria. These countries are confronted with two problems simultaneously: first, their GDP per capita is the lowest in the EU, second, the inequality is the highest.

The ratio of total income received by the $20 \%$ of the population with the highest income (top quintile) to that received by the $20 \%$ of the population with the lowest income (lowest quintile). 


\section{Maastricht criteria discipline in the EU Member States}

Unexpected macroeconomic analysis result is that the EU Member States that have achieved a high level of economic development take relatively less of financial discipline (the Maastricht criteria). These are the EU's largest economies - Germany, France, the United Kingdom and Italy. However, it must be recognized that such a high level of economic development of countries like Sweden, Denmark, Finland, Luxembourg, Belgium and the Netherlands, have sufficient fiscal discipline.

In the authors' opinion, new EU Member States, especially those, which economic performance is inferior, have no objective opportunities for strict adherence to the Maastricht criteria because of their insufficient economic potential. These criteria are too strict for them because in accordance with the fiscal and monetary discipline in these countries, unemployment rises catastrophically, wages decline, and this, in turn, reduces the state budget revenues, which creates a vicious circle.

The Maastricht criteria should be seen as a result rather than a tool for sustainable economic growth and a high level of development achievement. If these countries reach a level like the one of Sweden or Denmark, they will have the potential to comply with the fiscal and monetary discipline.

While examining the old EU Member States budget deficit data in 2000-2011, several important trends become apparent (Table 6).

First of all, it is clear that the Maastricht criteria - the state budget deficit requirement was followed just by the minority of countries, which amounted to only four (Denmark, Luxembourg, Finland and Sweden). The more developed EU countries' budget deficit was less than 3 percent throughout the covered period. Moreover, four countries violated the mentioned criteria in a relatively low rate (Ireland, Austria, Belgium and the Netherlands).

Table 6. Old EU Member States budget deficit, \% of GDP

\begin{tabular}{|l|c|c|c|c|c|c|c|c|c|c|c|c|}
\hline & $\mathbf{2 0 0 0}$ & $\mathbf{2 0 0 1}$ & $\mathbf{2 0 0 2}$ & $\mathbf{2 0 0 3}$ & $\mathbf{2 0 0 4}$ & $\mathbf{2 0 0 5}$ & $\mathbf{2 0 0 6}$ & $\mathbf{2 0 0 7}$ & $\mathbf{2 0 0 8}$ & $\mathbf{2 0 0 9}$ & $\mathbf{2 0 1 0}$ & $\mathbf{2 0 1 1}$ \\
\hline Belgium & 0.0 & 0.4 & -0.1 & -0.1 & -0.1 & -2.5 & 0.4 & -0.1 & -1.0 & -5.5 & -3.8 & -3.7 \\
\hline Denmark & 2.3 & 1.5 & 0.4 & 0.1 & 2.1 & 5.2 & 5.2 & 4.8 & 3.2 & -2.7 & -2.5 & -1.8 \\
\hline Germany & 1.1 & -3.1 & -3.8 & -4.2 & -3.8 & -3.3 & -1.6 & 0.2 & -0.1 & -3.1 & -4.1 & -0.8 \\
\hline Ireland & 4.7 & 0.9 & -0.4 & 0.4 & 1.4 & 1.7 & 2.9 & 0.1 & -7.4 & -13.9 & -30.9 & -13.4 \\
\hline Greece & -3.7 & -4.5 & -4.8 & -5.6 & -7.5 & -5.2 & -5.7 & -6.5 & -9.8 & -15.6 & -10.7 & -9.4 \\
\hline Spain & -0.9 & -0.5 & -0.2 & -0.3 & -0.1 & 1.3 & 2.4 & 1.9 & -4.5 & -11.2 & -9.7 & -9.4 \\
\hline France & -1.5 & -1.5 & -3.1 & -4.1 & -3.6 & -2.9 & -2.3 & -2.7 & -3.3 & -7.5 & -7.1 & -5.2 \\
\hline Italy & -0.8 & -3.1 & -3.1 & -3.6 & -3.5 & -4.4 & -3.4 & -1.6 & -2.7 & -5.4 & -4.5 & -3.9 \\
\hline Luxembourg & 6.0 & 6.1 & 2.1 & 0.5 & -1.1 & 0.0 & 1.4 & 3.7 & 3.2 & -0.8 & -0.8 & -0.3 \\
\hline The Netherlands & 2.0 & -0.2 & -2.1 & -3.1 & -1.7 & -0.3 & 0.5 & 0.2 & 0.5 & -5.6 & -5.1 & -4.5 \\
\hline Austria & -1.7 & 0.0 & -0.7 & -1.5 & -4.4 & -1.7 & -1.5 & -0.9 & -0.9 & -4.1 & -4.5 & -2.5 \\
\hline Portugal & -3.3 & -4.8 & -3.4 & -3.7 & -4.0 & -6.5 & -4.6 & -3.1 & -3.6 & -10.2 & -9.8 & -4.4 \\
\hline Finland & 7.0 & 5.1 & 4.2 & 2.6 & 2.5 & 2.9 & 4.2 & 5.3 & 4.4 & -2.5 & -2.5 & -0.6 \\
\hline Sweden & 3.6 & 1.5 & -1.3 & -1.0 & 0.6 & 2.2 & 2.3 & 3.6 & 2.2 & -0.7 & 0.3 & 0.4 \\
\hline $\begin{array}{l}\text { The United } \\
\text { Kingdom }\end{array}$ & 3.6 & 0.5 & -2.1 & -3.4 & -3.5 & -3.4 & -2.7 & -2.8 & -5.1 & -11.5 & -10.2 & -7.8 \\
\hline
\end{tabular}

Source: Eurostat data. ${ }^{4}$ 
The second trend, which should be mentioned, is that almost all of the major EU economies (Germany, France, Italy, the United Kingdom and Spain) usually allowed themselves to depart from this norm and to have a larger budget deficit even in a good economic period.

The third trend is that most of the more developed countries did not avoid to have large (10\% GDP and more) budget deficits, e.g. Ireland had $30.9 \%$ budget deficit in 2010, and $13.9 \%$ and $13.4 \%$ in 2009 and 2011 respectively, Greece had a budget deficit from $9.4 \%$ to $15.6 \%$ for the period of $2008-2011$, Spain's budget deficit was from $9.4 \%$ to $11.2 \%$ in $2009-2011$, the United Kingdom had a budget deficit from $7.8 \%$ to $11.5 \%$ in 2009-2011, whereas Portugal's budget deficit reached $10.2 \%$ and $9.8 \%$ in 2009 and 2011 respectively.

Compared to these countries public debt ratios (Table 8), it can be seen that the majority of the EU countries, trying to save their economies during the recession, did not pay attention to the Maastricht convergence criteria, although often requested it from other Member States.

Budget deficit data for the less developed countries seems to be similar (Table 7). Only Estonia complied with the above mentioned criteria during all period. All other countries failed to comply with the indicator normative for at least four years out of twelve. Poland and Hungary were unable to balance the budget properly during almost the entire analyzed period.

Table 7. New EU Member State budget deficit, \% of GDP

\begin{tabular}{|l|c|c|c|c|c|c|c|c|c|c|c|c|}
\hline & $\mathbf{2 0 0 0}$ & $\mathbf{2 0 0 1}$ & $\mathbf{2 0 0 2}$ & $\mathbf{2 0 0 3}$ & $\mathbf{2 0 0 4}$ & $\mathbf{2 0 0 5}$ & $\mathbf{2 0 0 6}$ & $\mathbf{2 0 0 7}$ & $\mathbf{2 0 0 8}$ & $\mathbf{2 0 0 9}$ & $\mathbf{2 0 1 0}$ & $\mathbf{2 0 1 1}$ \\
\hline Bulgaria & -0.5 & 1.1 & -1.2 & -0.4 & 1.9 & 1.0 & 1.9 & 1.2 & 1.7 & -4.3 & -3.1 & -2.0 \\
\hline $\begin{array}{l}\text { The Czech } \\
\text { Republic }\end{array}$ & -3.6 & -5.6 & -6.5 & -6.7 & -2.8 & -3.2 & -2.4 & -0.7 & -2.2 & -5.8 & -4.8 & -3.3 \\
\hline Estonia & -0.2 & -0.1 & 0.3 & 1.7 & 1.6 & 1.6 & 2.5 & 2.4 & -2.9 & -2.0 & 0.2 & 1.1 \\
\hline Cyprus & -2.3 & -2.2 & -4.4 & -6.6 & -4.1 & -2.4 & -1.2 & 3.5 & 0.9 & -6.1 & -5.3 & -6.3 \\
\hline Latvia & -2.8 & -2.0 & -2.3 & -1.6 & -1.0 & -0.4 & -0.5 & -0.4 & -4.2 & -9.8 & -8.1 & -3.4 \\
\hline Lithuania & -3.2 & -3.5 & -1.9 & -1.3 & -1.5 & -0.5 & -0.4 & -1.0 & -3.3 & -9.4 & -7.2 & -5.5 \\
\hline Hungary & -3.0 & -4.1 & -9.0 & -7.3 & -6.5 & -7.9 & -9.4 & -5.1 & -3.7 & -4.6 & -4.4 & 4.3 \\
\hline Malta & -5.8 & -6.4 & -5.8 & -9.2 & -4.7 & -2.9 & -2.8 & -2.3 & -4.6 & -3.9 & -3.6 & -2.7 \\
\hline Poland & -3.0 & -5.3 & -5.0 & -6.2 & -5.4 & -4.1 & -3.6 & -1.9 & -3.7 & -7.4 & -7.9 & -5.0 \\
\hline Romania & -4.7 & -3.5 & -2.0 & -1.5 & -1.2 & -1.2 & -2.2 & -2.9 & -5.7 & -9.0 & -6.8 & -5.5 \\
\hline Slovenia & -3.7 & -4.0 & -2.4 & -2.7 & -2.3 & -1.5 & -1.4 & 0.0 & -1.9 & -6.0 & -5.7 & -6.4 \\
\hline Slovakia & -12.3 & -6.5 & -8.2 & -2.8 & -2.4 & -2.8 & -3.2 & -1.8 & -2.1 & -8.0 & -7.7 & -4.9 \\
\hline
\end{tabular}

Source: Eurostat data. ${ }^{5}$

It should be noted that the EU member newcomers, even if they exceeded the criteria, they did not allow themselves to have a budget deficit of more than 5-7\% of GDP, even during the recession. Meanwhile, the economically stronger countries were not afraid to do this (already mentioned Irish and other examples).

5 Coloured indicator's values, which do not fit to the criterion normative. 
Estonia, Malta, Slovenia and Slovakia have already joined the euro zone. The impression is that almost all of these countries have complied with the criterion only for accession.

According to the criteria of public debt, the old EU members can be divided into three groups (Table 8): Northern, Central and Southern Europe countries.

Table 8. Old EU Member States public debt, \% of GDP

\begin{tabular}{|l|c|c|c|c|c|c|c|c|c|c|c|c|}
\hline & $\mathbf{2 0 0 0}$ & $\mathbf{2 0 0 1}$ & $\mathbf{2 0 0 2}$ & $\mathbf{2 0 0 3}$ & $\mathbf{2 0 0 4}$ & $\mathbf{2 0 0 5}$ & $\mathbf{2 0 0 6}$ & $\mathbf{2 0 0 7}$ & $\mathbf{2 0 0 8}$ & $\mathbf{2 0 0 9}$ & $\mathbf{2 0 1 0}$ & $\mathbf{2 0 1 1}$ \\
\hline EU-27 & 61.9 & 61.0 & 60.5 & 61.9 & 62.3 & 62.8 & 61.6 & 59.0 & 62.2 & 74.6 & 80.0 & 82.5 \\
\hline Belgium & 107.8 & 106.5 & 103.4 & 98.4 & 94.0 & 92.0 & 88.0 & 84.0 & 89.2 & 95.7 & 95.5 & 97.8 \\
\hline Denmark & 52.4 & 49.6 & 49.5 & 47.2 & 45.1 & 37.8 & 32.1 & 27.1 & 33.4 & 40.6 & 42.9 & 46.6 \\
\hline Germany & 60.2 & 59.1 & 60.7 & 64.4 & 66.2 & 68.5 & 68.0 & 65.2 & 66.8 & 74.5 & 82.5 & 80.5 \\
\hline Ireland & 35.1 & 35.2 & 32.0 & 30.7 & 29.5 & 27.3 & 24.6 & 25.1 & 44.5 & 64.9 & 92.2 & 106.4 \\
\hline Greece & 103.4 & 103.7 & 101.7 & 97.4 & 98.6 & 100.0 & 106.1 & 107.4 & 112.9 & 129.7 & 148.3 & 170.6 \\
\hline Spain & 59.4 & 55.6 & 52.6 & 48.8 & 46.3 & 43.2 & 39.7 & 36.3 & 40.2 & 53.9 & 61.5 & 69.3 \\
\hline France & 57.3 & 56.9 & 58.8 & 62.9 & 64.9 & 66.4 & 63.7 & 64.2 & 68.2 & 79.2 & 82.3 & 86.0 \\
\hline Italy & 108.5 & 108.2 & 105.1 & 103.9 & 103.4 & 105.7 & 106.3 & 103.3 & 106.1 & 116.4 & 119.2 & 120.7 \\
\hline Luxembourg & 6.2 & 6.3 & 6.3 & 6.1 & 6.3 & 6.1 & 6.7 & 6.7 & 14.4 & 15.3 & 19.2 & 18.3 \\
\hline $\begin{array}{l}\text { The } \\
\text { Netherlands }\end{array}$ & 53.8 & 50.7 & 50.5 & 52.0 & 52.4 & 51.8 & 47.4 & 45.3 & 58.5 & 60.8 & 63.1 & 65.5 \\
\hline Austria & 66.2 & 66.8 & 66.2 & 65.3 & 64.7 & 64.2 & 62.3 & 60.2 & 63.8 & 69.2 & 72.0 & 72.4 \\
\hline Portugal & 50.7 & 53.8 & 56.8 & 59.4 & 61.9 & 67.7 & 69.4 & 68.4 & 71.7 & 83.2 & 93.5 & 108.1 \\
\hline Finland & 43.8 & 42.5 & 41.5 & 44.5 & 44.4 & 41.7 & 39.6 & 35.2 & 33.9 & 43.5 & 48.6 & 49.0 \\
\hline Sweden & 53.9 & 54.7 & 52.5 & 51.7 & 50.3 & 50.4 & 45.3 & 40.2 & 38.8 & 42.6 & 39.5 & 38.4 \\
\hline $\begin{array}{l}\text { The United } \\
\text { Kingdom }\end{array}$ & 41.0 & 37.7 & 37.7 & 39.1 & 41.0 & 42.2 & 43.3 & 44.2 & 52.3 & 67.8 & 79.4 & 85.0 \\
\hline
\end{tabular}

Source: Eurostat data. ${ }^{6}$

Throughout the analyzed period, the criteria of the public debt ratio were observed only in the same four countries, which belong to the first group (Denmark, Luxembourg, Finland and Sweden). Four other countries, which belong to the second group (Ireland, the United Kingdom, the Netherlands and Spain), followed the agreed criteria until 2008, but during the time of crisis (2009-2011) these countries exceeded it. This was associated with a significant increase in the country's budget deficit to help the country's economy to recover from the recession. It is likely that in the future, when the economic situation will be improved, the indicator will decline by the agreed rates. Other countries, which form the third group, mostly failed to comply with the Maastricht criteria standards. First of all, these were the largest EU economies, Germany, France and Italy, and some smaller economies (Austria and Greece). These countries not only exceeded their target size, but they did not even try to reduce it. Germany, France and Austria did not create major problems (the public debt hovered around 60-70\% GDP), while in Italy and Greece the situation was much more serious. Throughout the analyzed period, the public debt of these countries was about 100\% GDP and sharply rocketed to $170 \%$ GDP in Greece and 120\% GDP in Italy alone over the years 2009-2011.

${ }_{6}$ Coloured indicator's values, which do not fit to the criterion normative. 
Belgium had a unique situation. The country's public debt was significantly higher than $60 \%$ GDP, but over the period of 2009 it systematically decreased.

Completely opposite situation was in the new EU Member States: most of them did not reach $60 \%$ GDP public debt limit. Exceptions are Cyprus, Malta and Hungary (for the sake of justice, Bulgaria should be distinguished, which in 2000 and 2001 exceeded the 60 percent threshold, but since then the rate has decreased significantly) (Table 9). Impressively, in this context Estonia also appears, which government debt has never reached $10 \%$ GDP.

Table 9. New EU Member States public debt, \% of GDP

\begin{tabular}{|l|c|c|c|c|c|c|c|c|c|c|c|c|}
\hline & $\mathbf{2 0 0 0}$ & $\mathbf{2 0 0 1}$ & $\mathbf{2 0 0 2}$ & $\mathbf{2 0 0 3}$ & $\mathbf{2 0 0 4}$ & $\mathbf{2 0 0 5}$ & $\mathbf{2 0 0 6}$ & $\mathbf{2 0 0 7}$ & $\mathbf{2 0 0 8}$ & $\mathbf{2 0 0 9}$ & $\mathbf{2 0 1 0}$ & $\mathbf{2 0 1 1}$ \\
\hline Bulgaria & 72.5 & 66.0 & 52.4 & 44.4 & 37.0 & 27.5 & 21.6 & 17.2 & 13.7 & 14.6 & 16.2 & 16.3 \\
\hline $\begin{array}{l}\text { The Czech } \\
\text { Republic }\end{array}$ & 17.8 & 23.9 & 27.1 & 28.6 & 28.9 & 28.4 & 28.3 & 27.9 & 28.7 & 34.2 & 37.8 & 40.8 \\
\hline Estonia & 5.1 & 4.8 & 5.7 & 5.6 & 5.0 & 4.6 & 4.4 & 3.7 & 4.5 & 7.2 & 6.7 & 6.1 \\
\hline Cyprus & 59.6 & 61.2 & 65.1 & 69.7 & 70.9 & 69.4 & 64.7 & 58.8 & 48.9 & 58.5 & 61.3 & 71.1 \\
\hline Latvia & 12.4 & 14.1 & 13.6 & 14.7 & 15.0 & 12.5 & 10.7 & 9.0 & 19.8 & 36.7 & 44.5 & 42.2 \\
\hline Lithuania & 23.6 & 23.0 & 22.2 & 21.0 & 19.3 & 18.3 & 17.9 & 16.8 & 15.5 & 29.3 & 37.9 & 38.5 \\
\hline Hungary & 56.1 & 52.7 & 55.9 & 58.6 & 59.5 & 61.7 & 65.9 & 67.0 & 73.0 & 79.8 & 81.8 & 81.4 \\
\hline Malta & 54.9 & 60.5 & 59.1 & 67.6 & 71.7 & 69.7 & 64.0 & 61.9 & 62.0 & 67.6 & 68.3 & 70.9 \\
\hline Poland & 36.8 & 37.6 & 42.2 & 47.1 & 45.7 & 47.1 & 47.7 & 45.0 & 47.1 & 50.9 & 54.8 & 56.4 \\
\hline Romania & 22.5 & 25.7 & 24.9 & 21.5 & 18.7 & 15.8 & 12.4 & 12.8 & 13.4 & 23.6 & 30.5 & 33.4 \\
\hline Slovenia & 26.3 & 26.5 & 27.8 & 27.2 & 27.3 & 26.7 & 26.4 & 23.1 & 22.0 & 35.0 & 38.6 & 46.9 \\
\hline Slovakia & 50.3 & 48.9 & 43.4 & 42.4 & 41.5 & 34.2 & 30.5 & 29.6 & 27.9 & 35.6 & 41.0 & 43.3 \\
\hline
\end{tabular}

Source: Eurostat data. ${ }^{7}$

Typically, almost all of these countries during the difficult economic situation (the period of 2009-2011) got rid of the public debt (some countries, e.g., Lithuania, twice or more just in 2-3 years time).

The EU Member States inflation criterion shows that economically stronger countries tend to have a more stable price level. Meanwhile, the less country is developed, the more often it exceeds the prescribed criteria.

In addition, country's situation according to this indicator was the best during the economic growth period, while during the downturn almost all countries were unable to cope with it.

\footnotetext{
Coloured indicator's values, which do not fit to the criterion normative.
} 
Table 10. Old EU Member State inflation, \%

\begin{tabular}{|l|c|c|c|c|c|c|c|c|c|c|c|}
\hline & $\mathbf{2 0 0 1}$ & $\mathbf{2 0 0 2}$ & $\mathbf{2 0 0 3}$ & $\mathbf{2 0 0 4}$ & $\mathbf{2 0 0 5}$ & $\mathbf{2 0 0 6}$ & $\mathbf{2 0 0 7}$ & $\mathbf{2 0 0 8}$ & $\mathbf{2 0 0 9}$ & $\mathbf{2 0 1 0}$ & $\mathbf{2 0 1 1}$ \\
\hline Criterion's value & 3,1 & 2,6 & 1,6 & 2,2 & 2,6 & 2,9 & 2,8 & 4,1 & 0,7 & 0,8 & 3,1 \\
\hline Luxembourg & 2.4 & 2.1 & 2.5 & 3.2 & 3.8 & 3.0 & 2.7 & 4.1 & 0.0 & 2.8 & 3.7 \\
\hline The Netherlands & 5.1 & 3.9 & 2.2 & 1.4 & 1.5 & 1.7 & 1.6 & 2.2 & 1.0 & 0.9 & 2.5 \\
\hline Austria & 2.3 & 1.7 & 1.3 & 2.0 & 2.1 & 1.7 & 2.2 & 3.2 & 0.4 & 1.7 & 3.6 \\
\hline Ireland & 4.0 & 4.7 & 4.0 & 2.3 & 2.2 & 2.7 & 2.9 & 3.1 & -1.7 & -1.6 & 1.2 \\
\hline Sweden & 2.7 & 1.9 & 2.3 & 1.0 & 0.8 & 1.5 & 1.7 & 3.3 & 1.9 & 1.9 & 1.4 \\
\hline Denmark & 2.3 & 2.4 & 2.0 & 0.9 & 1.7 & 1.9 & 1.7 & 3.6 & 1.1 & 2.2 & 2.7 \\
\hline Belgium & 2.4 & 1.6 & 1.5 & 1.9 & 2.5 & 2.3 & 1.8 & 4.5 & 0.0 & 2.3 & 3.5 \\
\hline $\begin{array}{l}\text { The United } \\
\text { Kingdom }\end{array}$ & 1.2 & 1.3 & 1.4 & 1.3 & 2.1 & 2.3 & 2.3 & 3.6 & 2.2 & 3.3 & 4.5 \\
\hline France & 1.8 & 1.9 & 2.2 & 2.3 & 1.9 & 1.9 & 1.6 & 3.2 & 0.1 & 1.7 & 2.3 \\
\hline Finland & 2.7 & 2.0 & 1.3 & 0.1 & 0.8 & 1.3 & 1.6 & 3.9 & 1.6 & 1.7 & 3.3 \\
\hline Germany & 1.9 & 1.4 & 1.0 & 1.8 & 1.9 & 1.8 & 2.3 & 2.8 & 0.2 & 1.2 & 2.5 \\
\hline Italy & 2.3 & 2.6 & 2.8 & 2.3 & 2.2 & 2.2 & 2.0 & 3.5 & 0.8 & 1.6 & 2.9 \\
\hline Spain & 2.8 & 3.6 & 3.1 & 3.1 & 3.4 & 3.6 & 2.8 & 4.1 & -0.2 & 2.0 & 3.1 \\
\hline Portugal & 4.4 & 3.7 & 3.3 & 2.5 & 2.1 & 3.0 & 2.4 & 2.7 & -0.9 & 1.4 & 3.6 \\
\hline Greece & 3.7 & 3.9 & 3.4 & 3.0 & 3.5 & 3.3 & 3.0 & 4.2 & 1.3 & 4.7 & 3.1 \\
\hline
\end{tabular}

Source: Eurostat data. ${ }^{8}$

According to the inflation criterion, the old members of the EU could be reasonably split into groups according to the level of the economic development (Table 10). First of all, countries, which were almost always able to satisfy the criteria, are the ones, which have major economies (Germany, France, the United Kingdom), the Nordic countries (Sweden, Finland, Denmark), as well as Austria and Belgium. Another group includes countries, which often exceeded the normative. These are economically more developed countries, such as Luxembourg, the Netherlands and Ireland. The last group contains EU Member States, which were usually hard-dealing with the rising prices. These are the economically less developed ones, such as Italy, Spain, Portugal and Greece.

Table 11. New EU Member States inflation, \%

\begin{tabular}{|l|c|c|c|c|c|c|c|c|c|c|c|}
\hline & $\mathbf{2 0 0 1}$ & $\mathbf{2 0 0 2}$ & $\mathbf{2 0 0 3}$ & $\mathbf{2 0 0 4}$ & $\mathbf{2 0 0 5}$ & $\mathbf{2 0 0 6}$ & $\mathbf{2 0 0 7}$ & $\mathbf{2 0 0 8}$ & $\mathbf{2 0 0 9}$ & $\mathbf{2 0 1 0}$ & $\mathbf{2 0 1 1}$ \\
\hline Normative & 3,1 & 2,6 & 1,6 & 2,2 & 2,6 & 2,9 & 2,8 & 4,1 & 0,7 & 0,8 & 3,1 \\
\hline Bulgaria & 7.4 & 5.8 & 2.3 & 6.1 & 6.0 & 7.4 & 7.6 & 12.0 & 2.5 & 3.0 & 3.4 \\
\hline $\begin{array}{l}\text { The Czech } \\
\text { Republic }\end{array}$ & 4.5 & 1.4 & -0.1 & 2.6 & 1.6 & 2.1 & 3.0 & 6.3 & 0.6 & 1.2 & 2.1 \\
\hline Estonia & 5.6 & 3.6 & 1.4 & 3.0 & 4.1 & 4.4 & 6.7 & 10.6 & 0.2 & 2.7 & 5.1 \\
\hline Cyprus & 2.0 & 2.8 & 4.0 & 1.9 & 2.0 & 2.2 & 2.2 & 4.4 & 0.2 & 2.6 & 3.5 \\
\hline Latvia & 2.5 & 2.0 & 2.9 & 6.2 & 6.9 & 6.6 & 10.1 & 15.3 & 3.3 & -1.2 & 4.2 \\
\hline Lithuania & 1.6 & 0.3 & -1.1 & 1.2 & 2.7 & 3.8 & 5.8 & 11.1 & 4.2 & 1.2 & 4.1 \\
\hline Hungary & 9.1 & 5.2 & 4.7 & 6.8 & 3.5 & 4.0 & 7.9 & 6.0 & 4.0 & 4.7 & 3.9 \\
\hline Malta & 2.5 & 2.6 & 1.9 & 2.7 & 2.5 & 2.6 & 0.7 & 4.7 & 1.8 & 2.0 & 2.5 \\
\hline
\end{tabular}

8 Coloured indicator's values, which do not fitto the criterion normative. 


\begin{tabular}{|l|c|c|c|c|c|c|c|c|c|c|c|}
\hline Poland & 5.3 & 1.9 & 0.7 & 3.6 & 2.2 & 1.3 & 2.6 & 4.2 & 4.0 & 2.7 & 3.9 \\
\hline Romania & 34.5 & 22.5 & 15.3 & 11.9 & 9.1 & 6.6 & 4.9 & 7.9 & 5.6 & 6.1 & 5.8 \\
\hline Slovenia & 8.6 & 7.5 & 5.7 & 3.7 & 2.5 & 2.5 & 3.8 & 5.5 & 0.9 & 2.1 & 2.1 \\
\hline Slovakia & 7.2 & 3.5 & 8.4 & 7.5 & 2.8 & 4.3 & 1.9 & 3.9 & 0.9 & 0.7 & 4.1 \\
\hline
\end{tabular}

Source: Eurostat data. ${ }^{9}$

The new EU Member States had the lowest criterion (Table 11). In fact, the more economically weaker is the country, the more difficult for it is to maintain a sufficient level of price stability. It should be noticed that the new members, which have already adopted the common currency, managed to keep the inflation rate within only a short period, which was just enough to join the euro zone.

\section{Conclusions}

1. Cohesion concept analysis cannot be limited only to the territorial and financial dimensions. The EU, as a rule, pays the most attention to the regional cohesion policy, while the economic cohesion remains less touched and focus on the social cohesion seems extremely low, e.g., as the main EU cohesion valuation indicators remain to be GDP and its derived parameters, furthermore, EMU convergence criteria are only macrofinancial. The cohesion policy must include at least three interrelated aspects of integration (economic, regional and social).

2. The EU Member States relative GDP analysis revealed several important trends in the period of 2000-2011. First, the more developed countries growth rates are very different. All less developed EU members are getting closer to the EU average. Meanwhile, some of the more developed countries (e.g., the Netherlands, Austria, Ireland, Sweden) are getting further away from it.

3. The last 12 years EU Member States' economic growth analysis showed that, on the one hand, the convergence between the largest (by the total GDP level) EU countries and the least developed (in terms of GDP per capita) member countries' economies is becoming clear. On the other hand, some other more developed countries (e.g., the Netherlands, Austria, Ireland, Sweden) continue to grow faster than the rest of the EU in general. Thus, the EU faces with the convergence and divergence processes at the same time.

4. The GDP growth analysis showed that the less developed countries had difficulties going through the recession. This, in turn, showed the threat of the EU cohesion policy in difficult economic times. It can be concluded that the EU's cohesion policy in the economic growth period was relatively effective, but encountered difficulties during the economic downturn.

5. The income inequality indicator's analysis confirmed that countries, which face greater difficulties in the economy, can be characterized as having greater inequality in income distribution. It can be argued that the total EU cohesion

9 Coloured indicator's values, which do not fit to the criterion normative. 
policy effectiveness depends on social cohesion policy enforcement efficiency. However, this statement requires to be studied further.

6. Summing up the Maastricht criteria analysis, it must be pointed out that in the EU there are only four countries, which comply with the convergence normative all the time (Sweden, Denmark, Luxembourg and Finland). The largest EU economies (Germany, France, the United Kingdom, Italy) could meet all criteria, but usually they do not do this. The least developed countries are totally unable to deal with the Maastricht indicators. Especially blank in this case seems to be Greece, Portugal, Spain and most part of Central and Eastern Europe countries.

7. The authors of the article agree with the view that the new EU Member States, especially those, which economic performance is inferior, have no objective opportunities for the adherence to the Maastricht criteria because their economic potential is not sufficient. These criteria are too strict for them because in accordance with the fiscal and monetary discipline, in these countries unemployment rises catastrophically, wages decline, and this, in turn, reduce the state budget revenues, which creates a vicious circle. The Maastricht criteria should be seen as a result rather than a tool to achieve sustainable economic growth and a high development level.

\section{References}

1. Barry, F. Economic Integration and Convergence Processes in the EU Cohesion Countries. JCMS. 2003 (41).

2. Battaini-Dragoni, G. and Dominioni, S. Conference on Social Cohesion. The Council of Europe's Strategy for Social Cohesion. 2003.

3. Begg, I. Complementing EMU: Rethinking Cohesion Policy. Oxford Review of Economic Policy. 2003 (19).

4. Brauers, W. K. M. and Ginevicius, R. Robustness in Regional Development Studies. The Case of Lithuania. Journal of Business Economics and Management. 2009, (10).

5. Buiter, W.; Corsetti, G. and Roubini, N. Excessive Deficits: Sense and Nonsense in the Treaty of Maastricht. Economic Policy. 1993 (16).

6. Burbulyte, G. Regiono sampratos ịvairovè regioniniuose tyrimuose. Tiltai. 2005, 4.

7. Calvo, M. A. M.; Cuadrado-Roura, J. R. and Garrido-Yserte, R. Economic and Social Cohesion in the EU: A Critical Approach. 44th European Congress of The Regional Science Association. 2004.

8. Chan, J.; Ho-Pong, T. and Chan, E. Reconsidering Social Cohesion: Developing a Definition and Analytical Framework for Empirical Research. Social Indicators Research. 2006.

9. Dragojevic, S. Social Cohesion and Culture: Contrasting Some European and Canadian Approaches and Experiences. Culturelink Review. 2001.

10. Ezcurra, R.; Gil, C. and Pascual, P. Regional Welfare Disparities: The Case of the European Regions. Applied Economics. 2005 (37). 
11. Fitoussi, J.-P.; Sen, A. and Stiglitz., J. Report by the Commision on the Measurement of Economic Performance and Social Progress. 2009 [interactive]. [accessed on dd-mmyyyy]. <http://www.stiglitz-sen-fitoussi.fr/documents/rapport_anglais.pdf >.

12. Garcia, I. P. Spanish Regional Policy: Economic and Social Cohesion in the European Union. IAER. 2003 (9).

13. Green Paper on Territorial Cohesion Turning Territorial Diversity into Strength. Communication from the Commission to the Council, the European Parliament, the Committee of the Regions and the European Economic and Social Committee. 2008.

14. Hulse, K. and Stone, W. Social Cohesion, Social Capital and Social Exclusion. Policy Studies. 2007 (28).

15. Kilijonienè, A. and Simanavičienè, Ž. Evaluation Model of Regional Policy's Influence on Social and Economical Development of the Region. Economics and Management. 2009 (14).

16. Kosiedowski, W. Teoretyczne Problemy Rozwoju Regionalnego. Zarzadzanie Rozwojem Regionalnym i Lokalnym: Problemy Teorii i Praktyki. Torun: Dom Organizatora, 2001.

17. Stanley, D. Holding the Centre: What We Know About Social Cohesion. Strategic Research and Analysis and the Social Cohesion Network. 2001.

\section{EUROPOS SĄJUNGOS SANGLAUDOS POLITIKOS IGYVENDINIMO TENDENCIJOS IR YPATYBĖS ŠALYSE SENBUVĖSE IR NAUJOKĖSE}

Santrauka. Europos Sąungos auganti tarptautinė veikla ir svarbus vaidmuo pasaulio ekonomikoje nukreipti visų pirma ị naujų ES narių ekonomikos raidą ir ekonominės krizès padarinių įveikimą. Šio proceso metu iškyla ịvairių klausimų. Kodèl kai kurios ES narių ekonomikos atsigauna greičiau po ekonominès krizès, o kitų šalių narių ekonomikos stagnuoja, esant artimiems nuliui arba net neigiamiems augimo tempams? Kokie teigiami ir neigimai pokyčiai ịvyko naujokèse ir senbuvèse ES šalyse narėse? Ar ES išplètimas ir naujų narių priëmimas yra ekonominiu požiūriu pateisinamas? Ar ES plètra eina teisingu keliu? Kuriuo atveju prièmus sprendimą dèl ES pletros padarytos klaidos?

Šis procesas iškelia tiek naujų grèsmių, tiek plètros galimybių. Ar situacija bus palanki darniam ir efektyviam ES ekonomikos augimui, priklausys nuo sẻkmingo ES sanglaudos politikos igyvendinimo ir atsako ị naujus iššūkius ịgyvendinant sanglaudos politiką ateityje.

Socialinè ir ekonominè sanglauda yra solidarumo tarp ES šalių narių ir ES teritorinių regionų išraiška. Tikslas yra pasiekti subalansuotą ES šalių narių ir regionų plètrą, mažinant struktūrinius netolygumus tarp šalių ir regionų bei skatinant lygias galimybes visiems. Sanglaudos politika turi didelę ịtaką ES šalių ekonomikai, mažindama ekonominius skirtumus ir skatindama aplinkosauginę ir socialinę plètrą. Ji taip pat vaidina svarbų vaidmenị paskirstant ES struktūrinių fondų lèšas, padedant švelninti ekonominès krizès pasekmes ES šalių narių ekonomikoms, gyventojams ir verslui.

ES šalys narès pasižymi dideliais ekonominès raidos lygio skirtumais, galima sakyti, kad ES yra ịvairių greičių Europa: senų ir naujų ES šalių narių socialinè ir ekonominè raida ženkliai skiriasi. Be to, ES šalys narès (apimant dvi šalių grupes) pasižymi ekonominès ir socialinès sanglaudos konvergencija bei divergencija. 
Ona Gražina RAKAUSKIENE் - Habil. Dr. in Economics; professor of Institute of Economics and Business, Faculty of Economics and Finance Management, Mykolas Romeris University. Scientific research area - economics of the European Union; international economics; quality of life of population; gender economics.

Ona Gražina RAKAUSKIENE் - Mykolo Romerio universiteto Ekonomikos ir finansų valdymo fakulteto Ekonomikos ir verslo instituto profesoré, ekonomikos mokslų habilituota daktarè. Mokslinių tyrimų sritys: Europos Sąjungos ekonomika, tarptautinė ekonomika gyventojų gyvenimo kokybè, lyčių ekonomika.

Viktor KOZLOVSKIJ - PhD student in Economics at Mykolas Romeris University; lector of Faculty of Business Management, Vilniaus Kolegija/University of Applied Sciences. Scientific research area - economics of the European Union; Welfare economics.

Viktor KOZLOVSKIJ - Mykolo Romerio universiteto Ekonomikos ir finansų valdymo fakulteto Ekonomikos ir verslo instituto doktorantas, Vilniaus kolegijos Verslo vadybos fakulteto lektorius. Mokslinių tyrimų sritys: Europos Sąungos ekonomika, gerovès ekonomika. 